\title{
Winter habitat of Xylophilus ampelinus, the cause of bacterial blight of grapevine, in Japan
}

\author{
Tsutomu Komatsu • Norio Kondo
}

Received: 2 July 2014/ Accepted: 5 October 2014/Published online: 17 January 2015

(c) The Author(s) 2015. This article is published with open access at Springerlink.com

\begin{abstract}
Xylophilus ampelinus, the cause of bacterial blight of grapevine, was first identified in 2009 in Hokkaido, Japan. We investigated the distribution of $X$. ampelinus in grapevines and its winter habitat in Hokkaido. After defoliation of artificially infected potted plants, new branches were cut and stored in plastic bags at $5{ }^{\circ} \mathrm{C}$ in the dark for 60 days. PCR analysis of samples from the stored branches using a pathogen-specific primer set detected $X$. ampelinus in the axillary buds but not in the epidermis and vascular bundle. In the naturally infected vineyards, we confirmed the presence of $X$. ampelinus in the axillary buds and in the vascular bundles at defoliation. However, the pathogen DNA was not detected in the vascular bundles or sap after overwintering. In contrast, the detection frequency in whole axillary buds decreased only slightly, even after overwintering. Additionally, the bacteria were detected in cold-stored bracts and wool at a higher frequency than in the interior axillary bud tissues. Our findings indicate that $X$. ampelinus likely is not maintained inside tissues or sap and that it might not survive on plant surfaces; rather, bacteria can be found on the underside surface of the bract and bud wool during winter in Hokkaido.
\end{abstract}

Keywords Xylophilus ampelinus - Bacterial blight . Grapevine $\cdot$ Overwintering $\cdot$ Bud

T. Komatsu $(\square) \cdot$ N. Kondo

Research Faculty of Agriculture, Hokkaido University, Kita 9,

Nishi 9 Kita-ku, Sapporo 060-8589, Japan

e-mail: komatsu-tsutomu@hro.or.jp

T. Komatsu

Hokkaido Research Organization, Central Agricultural

Experiment Station, Naganuma, Hokkaido 069-1395, Japan

\section{Introduction}

Xylophilus ampelinus (Panagopoulos 1969) (Willems et al. 1987) causes bacterial blight of grapevine in its only known host, Vitis vinifera (Panagopoulos 1980). Symptoms include cracks and cankers along shoots, discoloration of xylem tissues, angular necrotic lesions on leaves, and death of the infected canes and branches (Lopez et al. 1981; Ridé and Marcelin 1983). Severe infection can lead to serious harvest losses, because the infected branch is usually destroyed. Unfortunately, chemical agents do not aid in disease control (Panagopoulos 1987).

In Japan, the first outbreak of the disease occurred in Hokkaido Prefecture in 2009 (Shinmura et al. 2012), and diseased plants were distributed throughout the vineyard. The symptoms were originally confused with the dead arm of grapevine caused by Phomopsis viticola, a fungal pathogen that is abundant in Hokkaido. Therefore, almost all grape producers applied fungicides, that failed to control the disease, leading to the discovery of the causal bacterium (Shinmura et al. 2012).

The disease is associated with cool and moist conditions. The causative bacterium is transmitted via moist wind, rain, and sprinkled irrigation (Bradbury 1991). Evidence also indicates that the bacteria are mechanically transmitted via shear blades during pruning and harvesting (Ridé et al. 1977). Indeed, the bacterium was isolated from pruning shears and harvesting machine blowers in France (Ridé 2000). Therefore, bleeding sap is likely an important source of contamination. However, contamination was not replicated using an experimental pruning procedure in autumn in Hokkaido (T. Komatsu, unpublished data). The aim of the present study was to examine the ecology of $X$. ampelinus in Hokkaido vineyards by determining the bacterial distribution within specific plant tissues after 
defoliation and overwintering in the vineyard and within detached branches after storage.

\section{Materials and methods}

Artificial inoculation

In March 2012, the branches of three primary winemaking grape varieties, Kerner, Zweigeltrebe and Seibel 5279, growing in the vineyard of the Central Agricultural Experiment Station, Hokkaido Research Organization were cut from healthy grapevines. Each branch was planted in a plastic pot $(12 \mathrm{~cm}$ diameter $\times 15 \mathrm{~cm}$ high $)$ filled with Kanuma soil (a weathered pumice) and horticultural soil (Takii \& Co., Kyoto, Japan) mixed at a 1:1 ratio $(\mathrm{v} / \mathrm{v})$. Branches were grown in a greenhouse at the Experimental Station. In May 2012, 40 pots per cultivar of plants that had grown roots and new branches were moved to an enclosure $(3 \mathrm{~m}$ high $\times 15 \mathrm{~m}$ long $\times 5.4 \mathrm{~m}$ wide) covered with a water-permeable shade (50\% reduction of far infrared light, $15 \mathrm{~m}$ long $\times 8 \mathrm{~m}$ wide; Megacool, Mitsubishi Plastics Agri Dream Co., Tokyo, Japan).

Xylophilus ampelinus strains BB-7 and BB-9 (isolated from Kerner and Zweigeltrebe, respectively, in Yoichi, Hokkaido in 2009) were shake-cultured in $100 \mathrm{~mL}$ of nutrient broth $(10 \mathrm{~g}$ beef extract, $10 \mathrm{~g}$ bacto-peptone, and $3 \mathrm{~g} \mathrm{NaCl} / 1,000 \mathrm{~mL}, \mathrm{pH} \mathrm{7.2)}$ at $125 \mathrm{rpm}$ and $25^{\circ} \mathrm{C}$ for 7 days. The two bacterial suspensions were mixed and diluted with distilled water to $1,000 \mathrm{~mL}$, and the bacterial suspension $(2 \mathrm{~mL})$ was applied to each leaf of 30 potted grape plants using a hand sprayer on five consecutive days at three times: June 8-12, July 9-13, and August 24-28, 2012. Suspensions of $1.09 \times 10^{7}$ colony forming units $(\mathrm{cfu}) / \mathrm{mL}, \quad 6.74 \times 10^{9} \mathrm{cfu} / \mathrm{mL}$, and $9.67 \times 10^{9} \mathrm{cfu} / \mathrm{mL}$ were prepared just before the inoculation. Ten potted grape plants were sprayed with the same amount of water without inoculum as controls. After inoculation, the plants were covered with a plastic sheet $(0.9 \mathrm{~m}$ long $\times 1.8 \mathrm{~m}$ wide $)$ until the next morning to maintain high humidity. Potted grape plants were watered by sprinkling the soil and the leaf surface daily with water in the morning if it was not raining.

The incidence of diseased leaves was assessed on October 3, 2012. After defoliation on November 20, almost all individuals had one new branch with multiple buds; each new branch was cut off, leaving two buds on the grape plant, and the branches were stored in plastic bags at $5{ }^{\circ} \mathrm{C}$ in the dark for 60 days. The presence of $X$. ampelinus in the axillary buds, epidermis, and vascular bundles was determined in triplicates of 15 branches of each cultivar.

\section{Natural infection}

To determine the bacterial distribution in grapevines, plant samples were collected from vineyards 1 (Kerner in Yoichi), 2 (Zweigeltrebe in Furano, Hokkaido), and 3 (New York Muscat in Furano). The disease frequencies recorded for the leaves were 1.3 and $3.7 \%$ in vineyards 1 and 2 (September 2012), respectively, and $9.8 \%$ in vineyard 3 (September 2013). In vineyard 3, 20 samples of axillary buds and vascular bundles from 60 pruned branches of 20 trees were collected after all the leaves had fallen in October 2013. After overwintering, one sample each of the axillary buds, sap, and vascular bundles was collected per tree before sprouting from the end of April to the beginning of May 2013 from vineyards 1 and 2 and from the end of April 2014 from vineyard 3 . The first leaves that developed at the bases of the branches and the spikes were collected as one sample per tree from the beginning to middle of June 2013 from vineyards 1 and 2 and from the end of May to the middle of June 2014 from vineyard 3 . Further, the remaining branches collected from vineyard 3 in October 2013 were stored in a plastic bag at $5{ }^{\circ} \mathrm{C}$ in the dark. The axillary buds were classified into bract, wool, and tissues inside axillary buds and were analyzed after storage for 50 days. The 20 samples were analyzed for the presence of $X$. ampelinus. These experiments were conducted in triplicate.

\section{Asymptomatic samples}

In August 2013, leaves were collected as one sample per tree from the five commercial vineyards in Yoichi as follows: vineyards 4-7 with cultivated Kerner and 8 with cultivated Kerner and Sauvignon Blanc. All vineyards were highly infected in 2009 and 2010, whereas all of the plants in these vineyards were asymptomatic in 2013. Twenty shoots (approximately $20 \mathrm{~cm}$ long) were collected from plants from each of the vineyards to analyze for DNA of $X$. ampelinus.

\section{DNA extraction and PCR analysis}

To extract DNA from the vascular bundle tissue, the epidermis and cortex were scraped off with a sterilized razor blade, and a 10-mm length of the stele was excised and immersed in $100 \mu \mathrm{L}$ of TE buffer $(100 \mathrm{mM}$ Tris- $\mathrm{HCl}$, $1 \mathrm{mM}$ EDTA, $\mathrm{pH}$ 8.0) to soften it. The stele was then ground using sand paper (\#100, Holt Production Ltd., UK) according to the method of Nakaune and Nakano (2006). This paste of macerated tissue was added to $400 \mu \mathrm{L}$ of AP1 buffer from the DNeasy Plant Mini Kit (Qiagen, Hilden, Germany) and placed into a new microcentrifuge tube. Three layers of epidermis ( $10 \mathrm{~mm}$ long $\times 2 \mathrm{~mm}$ wide), three buds, a $1-\mathrm{cm}^{2}$ section of leaf, and a $5-\mathrm{mm}$ spur were 
softened separately in $100 \mu \mathrm{L}$ of TE buffer. The respective samples were then homogenized with a sterilized mortar and pestle. Immediately after the branches were pruned in April 2013 and 2014, approximately $1.0 \mathrm{~mL}$ of the oozing sap was collected in $1.5 \mathrm{~mL}$ microcentrifuge tubes from each cut surface. In 2013, to culture any bacteria in the sap, $100 \mu \mathrm{L}$ of sap was mixed with $900 \mu \mathrm{L}$ of nutrient broth in a $2 \mathrm{~mL}$ tube and incubated at $25{ }^{\circ} \mathrm{C}$ with shaking at $125 \mathrm{rpm}$ for 7 days. The broth was then plated on King's B medium (Eiken Chemical Co., Tochigi, Japan) and incubated at $25{ }^{\circ} \mathrm{C}$. After 10 days of incubation, the morphology of the bacterial colonies was recorded, and 10 colonies were isolated with sterilized toothpicks and suspended in $50 \mu \mathrm{L}$ of sterilized distilled water. The suspension was heated at $95{ }^{\circ} \mathrm{C}$ for $10 \mathrm{~min}$ and then cooled rapidly for 5 min on ice; after centrifugation, the supernatant was used in PCR analysis as described in the next paragraph. In addition to bacterial culture supernatant, in 2014, intact sap was obtained without pre-cultivation to detect bacteria using PCR.

DNA was extracted from plant organs and intact sap using the DNeasy Plant Mini Kit according to the manufacturer's instructions. Amplification reactions included $1 \mu \mathrm{L}$ of DNA and $24 \mu \mathrm{L}$ of reaction mixture: $1 \mu \mathrm{M}$ of each primer (XaTS1; 5'-TGCGTAGTTCAACACCAAAGT-3', XaTS2; 5'-TATGACCCTCTTTCCACCAGC-3'), $1.25 \mathrm{U}$ of ExTaq DNA polymerase (Takara Bio, Shiga, Japan), $200 \mu \mathrm{M}$ dNTP mixture, and $1 \times$ PCR buffer with $\mathrm{MgCl}_{2}$. Amplification conditions were as follows: initial denaturation at $94{ }^{\circ} \mathrm{C}$ for $5 \mathrm{~min} ; 40$ cycles at $94{ }^{\circ} \mathrm{C}$ for $30 \mathrm{~s}, 60{ }^{\circ} \mathrm{C}$ for $45 \mathrm{~s}$, and $72{ }^{\circ} \mathrm{C}$ for $45 \mathrm{~s}$; and a final extension at $72{ }^{\circ} \mathrm{C}$ for $8 \mathrm{~min}$ (Manceau et al. 2005). To prove that there was no interference of inhibitory substances in the extracts of the buds and vascular bundles, 20 DNA samples were highly purified with Mag Extractor Plant Genome (Toyobo Co., Tokyo, Japan), which is effective for purifying nucleic acids extracted from soil (Kageyama et al. 2003), and the aforementioned PCR method was repeated. PCR products were subjected to agarose gel $(1.5 \% \mathrm{w} / \mathrm{v})$ electrophoresis for $30 \mathrm{~min}$ at $100 \mathrm{~V}$, and the amplicons were detected by staining the gels with $0.01 \%$ (v/v) Gel Red (Wako Pure Chemical Industries, Tokyo, Japan).

\section{Results}

Artificial inoculation

Potted grapevine plants inoculated with $X$. ampelinus exhibited the typical symptoms of bacterial blight on every branch. We examined all leaves and counted diseased leaves. Kerner had 405 diseased leaves (163 healthy), Seibel5279 had 619 diseased (172 healthy), and Zweigeltrebe had 567 (172 healthy). The frequency of diseased leaves, in order of most frequent, was thus $23.8 \%(\mathrm{SE} \pm 2.8)$ on Seibel 5279, $21.7 \%(\mathrm{SE} \pm 11.8)$ on Kerner, and $17.7 \%$ ( $\mathrm{SE} \pm 3.5)$ on Zweigeltrebe in September 2012. The analysis of cut branches stored at $5{ }^{\circ} \mathrm{C}$ for 60 days revealed the presence of $X$. ampelinus in $100 \%$ of the axillary buds of Kerner and Zweigeltrebe and in $80 \%$ of Seibel 5279, but not in the epidermis or vascular bundle (Table 1; Fig. 1). Symptoms and pathogen-specific DNA were not detected in the controls inoculated with water.

\section{Natural infection}

In plants with a high incidence of diseased leaves in vineyard 3 in 2013, the presence of X. ampelinus was detected in $100 \%$ of whole axillary buds and vascular bundles immediately after defoliation (Table 2; Fig. 2a). The whole axillary buds had a high number of positive reactions for $X$. ampelinus-specific DNA in the spring of 2013 (21.7\% in vineyard 1 and $40.0 \%$ in vineyard 2$)$ and 2014 (63.3\% in vineyard 3; Table 2; Fig. 2b). We observed a few bacterial colonies on the plates inoculated with incubated sap in 2013, but none had the characteristic features of $X$. ampelinus, e.g., non-mucoid, smooth, yellow, round, and fully circular colonies. Further, DNA specific for $X$. ampelinus was not detectable by PCR amplification from any colony or from intact sap collected in 2014 from vineyard 3 (Table 2; Fig. 2c), nor from the vascular bundles after overwintering (Table 2; Fig. 2d). In contrast, the DNA frequency in the whole axillary bud only slightly decreased after overwintering (Table 2; Fig. 2b). Although the first leaves that developed at the bases of the branches and spikes were asymptomatic, they were positive for DNA of X. ampelinus (Table 2; Fig. 2e). In addition, similar amplification patterns were observed for DNA samples prepared using only the DNeasy Plant Mini Kit versus using the highly purified DNA samples (data not shown).

The frequency of DNA of $X$. ampelinus in the cold-stored bract and wool segments of the axillary bud was particularly high at $96.7 \%$. The DNA was detected even in the tissues inside axillary buds, but only in $23.3 \%$ of the tested tissues.

Detection of $X$. ampelinus from asymptomatic plants

In 2013, pathogen-specific DNA was detected in 5-30\% of the leaves collected from asymptomatic plants, which were diseased in 2009 (Table 3).

\section{Discussion}

Xylophilus ampelinus grows very slowly on artificial media and forms visible colonies only after 10 days of 
Table 1 Detection of Xylophilus ampelinus in artificially inoculated branches removed from potted Vitis vinifera

\begin{tabular}{|c|c|c|c|c|c|}
\hline \multirow[t]{3}{*}{ Inoculation $^{\mathrm{a}}$} & \multirow[t]{3}{*}{ Cultivar } & \multirow{3}{*}{$\begin{array}{l}\text { Disease leaves }(\%)^{\mathrm{b}} \\
\text { Before defoliation }\end{array}$} & \multicolumn{3}{|c|}{ PCR detection $(\%)$} \\
\hline & & & \multicolumn{3}{|c|}{60 days after storage at $5^{\circ} \mathrm{C}$} \\
\hline & & & Buds & Epidermis & Vascular bundles \\
\hline \multirow[t]{3}{*}{ Inoculated } & Kerner & 21.7 & 100 & 0 & 0 \\
\hline & Seibel 5279 & 23.8 & 80 & 0 & 0 \\
\hline & Zweigeltrebe & 17.7 & 100 & 0 & 0 \\
\hline \multirow[t]{3}{*}{ Uninoculated } & Kerner & 0 & 0 & 0 & 0 \\
\hline & Seibel 5279 & 0 & 0 & 0 & 0 \\
\hline & Zweigeltrebe & 0 & 0 & 0 & 0 \\
\hline
\end{tabular}

${ }^{a}$ Potted $V$. vinifera (30) were inoculated by spraying with $X$. ampelinus strain BB-7 and BB-9 suspensions, and 10 potted $V$. vinifera served as Controls (uninoculated) and were sprayed with water

${ }^{\mathrm{b}}$ Percentage of diseased leaves of total leaves analyzed. Total leaf numbers: inoculated- Kerner, 405; Seibel 5279, 619; and Zweigertrebe, 567. Total leaf numbers: uninoculated- Kerner, 163; Seibel 5279, 172; Zweigeltrebe, 172

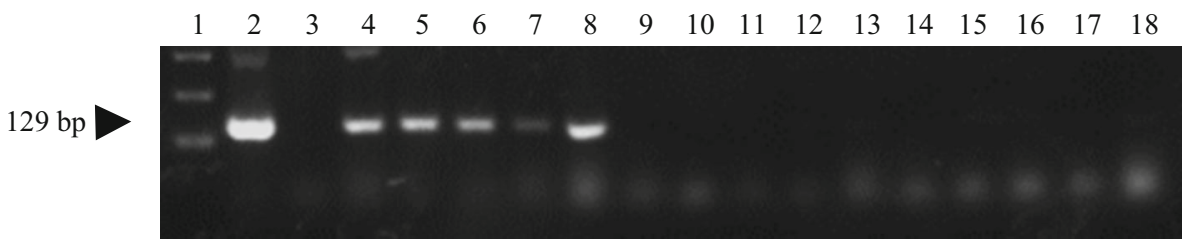

Fig. 1 PCR detection of Xylophilus ampelinus in detached, inoculated branches of grapevine (Kerner) stored at $5{ }^{\circ} \mathrm{C}$ for 60 days. Lanes: $1100 \mathrm{bp}$ ladder; 2 X. ampelinus (129 bp, positive control); 3

sterile distilled water (negative control); 4-8 buds; 9-13 epidermis; 14-18 vascular bundles

Table 2 Detection of Xylophilus ampelinus in the tissues of naturally infected Vitis vinifera in commercial vineyards

\begin{tabular}{|c|c|c|c|c|c|c|c|}
\hline \multirow[t]{3}{*}{ Vineyard number } & \multicolumn{7}{|c|}{ PCR detection rate $(\%)$} \\
\hline & \multicolumn{2}{|c|}{ After defoliation } & \multicolumn{5}{|c|}{ After overwintering $^{\mathrm{a}}$} \\
\hline & Bud & Vascular bundle & Buds & Saps & Vascular bundles & Leaves & Spikes \\
\hline 1 & n.t. & n.t. & 21.7 & 0 & 0 & 0 & 30 \\
\hline 2 & n.t. & n.t. & 40.0 & 0 & 0 & 45 & 85 \\
\hline 3 & 100 & 100 & 63.3 & 0 & 0 & 70 & 70 \\
\hline
\end{tabular}

Plant samples were collected from vineyard 3 just after defoliation in October 2013

n.t. not tested

${ }^{a}$ Plant samples were collected in 2013 from vineyard 1 and 2 and in 2014 from vineyard 3. The buds, vascular bundles, and sap were collected before sprouting

culture (Bradbury 1991). Furthermore, because selective medium is not available, saprophytic bacteria may easily overgrow the pathogen. Therefore, we examined samples using PCR with primers that were developed by Manceau et al. (2005) specifically to amplify the DNA of $X$. ampelinus. Amplification of the specific DNA from grapevine tissues is generally difficult because of the high concentrations of inhibitory substances in plant extracts (Minsavage et al. 1994; Rowhani et al. 1993). However, we observed similar amplification patterns for DNA samples prepared using only a DNA extraction kit and for highly purified DNA samples. Therefore, we concluded that the DNA samples prepared from grapevine tissues by using the extraction kit were suitable to detect $X$. ampelinus. Additionally, any negative results could not be attributed to the presence of inhibitors in the DNA preparation because we used improved DNA extraction technology. 
Fig. 2 PCR detection of Xylophilus ampelinus in naturally infected grapevines in vineyard 3. Panels: a buds (lanes 4-13) and vascular bundles (lanes 14-23) collected just after defoliation in 2013; b bud (lanes 4-23); c sap (lanes 4-23); d vascular bundle (lanes 4-23); e leaves (lanes 4-13) and spikes (lanes 14-23) collected after overwintering in 2014. All panels, lanes: 1100 bp ladder; 2 $X$. ampelinus (129 bp, positive control); and 3 sterile distilled water (negative control)
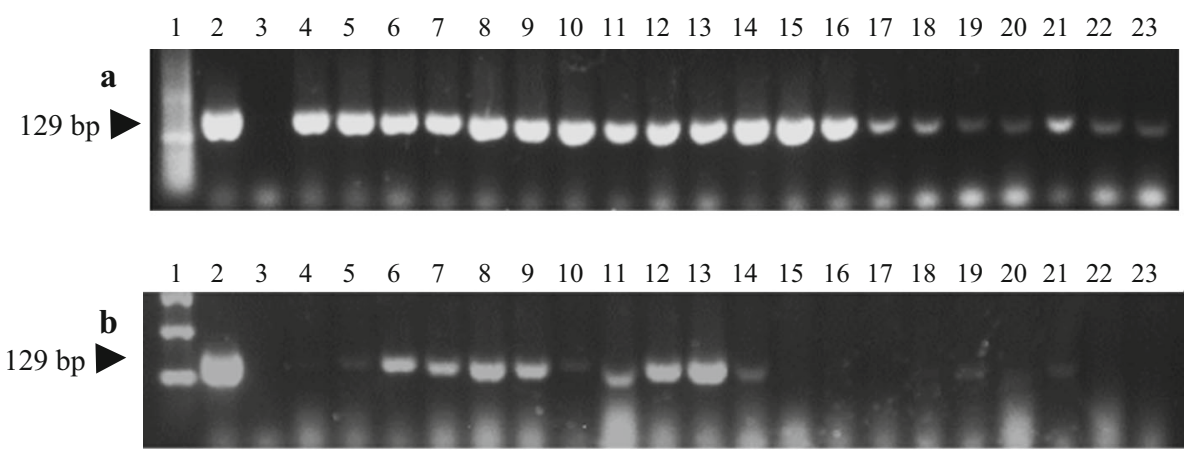

$\begin{array}{lllllllllllllllllllllll}1 & 2 & 3 & 4 & 5 & 6 & 7 & 8 & 9 & 10 & 11 & 12 & 13 & 14 & 15 & 16 & 17 & 18 & 19 & 20 & 21 & 22 & 23\end{array}$

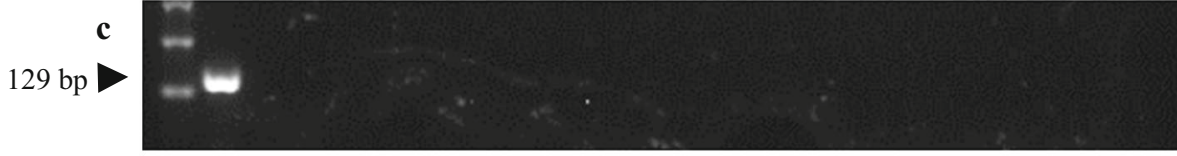

$\begin{array}{lllllllllllllllllllllll}1 & 2 & 3 & 4 & 5 & 6 & 7 & 8 & 9 & 10 & 11 & 12 & 13 & 14 & 15 & 16 & 17 & 18 & 19 & 20 & 21 & 22 & 23\end{array}$

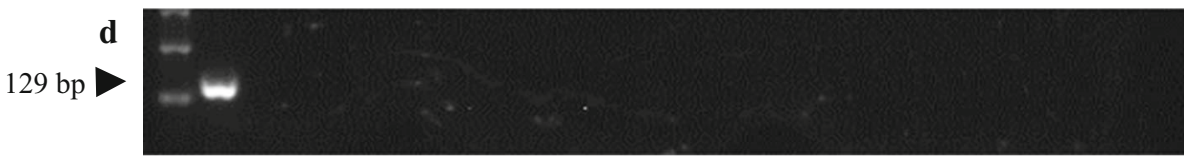

$\begin{array}{lllllllllllllllllllllll}1 & 2 & 3 & 4 & 5 & 6 & 7 & 8 & 9 & 10 & 11 & 12 & 13 & 14 & 15 & 16 & 17 & 18 & 19 & 20 & 21 & 22 & 23\end{array}$

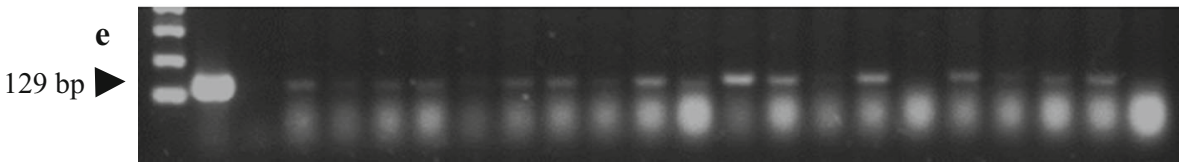

Table 3 Detection of Xylophilus ampelinus in asymptomatic leaves from commercial vineyard in Yoichi in 2013

\begin{tabular}{lll}
\hline Vineyard number & Cultivar & $\begin{array}{l}\text { PCR detection } \\
\text { rate }(\%)\end{array}$ \\
\hline 4 & Kerner & 15 \\
5 & Kerner & 10 \\
6 & Kerner & 5 \\
7 & Kerner & 15 \\
8 & Kerner & 10 \\
8 & Sauvignon Blanc & 30 \\
\hline
\end{tabular}

To determine the distribution of $X$. ampelinus within grapevines, we analyzed infected plants for the presence of pathogen-specific DNA after the growing season. In France, $X$. ampelinus was found in the sap and old vascular bundles (Grall et al. 2005). In contrast, in Hokkaido, we detected the bacterium only in the axillary buds in the spring before sprouting in the highly infected vineyard; however, $X$. ampelinus DNA was detected in the vascular bundle and in buds immediately after defoliation in autumn (Table 2; Fig. 2a). These results indicate that, in Hokkaido, $X$. ampelinus likely hibernates in the bud rather than in the sap or the vascular bundle. The northern European varieties that are mainly cultivated in Hokkaido differ from those cultivated in France, and $X$. ampelinus is not the causal agent in northern Europe (OEPP/EPPO 2013; https://www. eppo.int/QUARANTINE/listA2.htm). Further, Hokkaido is located in a subarctic zone where the average temperature is below freezing for approximately 4 months (from the last half of November to the first half of March). Therefore, we think that the difference in bacterial strains and/or winter temperatures determines which part of the plant the bacterium inhabits during latency.

The bacterium spreads by wind and rain in Europe (Panagopoulos 1987). The bacterium most likely also spreads in Hokkaido via these modes because potted healthy grapevines were infected after they were placed between diseased plants (T. Komatsu, unpublished data). Moreover, the bacteria were detected in the bracts and wool at a higher frequency than in the tissues inside axillary buds. Grall and Manceau (2003) found that, although bacteria primarily formed colonies in the vascular bundles after scratch inoculations, the bacteria did not spread to the new shoot. This observation indicates that it is difficult for $X$. ampelinus to migrate through plant tissues, leading us to conclude that the bacteria are transported mainly along the surface of the vine by water or wind to the axillary buds 
without entering the plant. The bacterium was not detected on the epidermis of branches that were refrigerated (Table 1), indicating that the bacterium might not survive on the plant surface during winter. Therefore, we surmised that only the bacteria inhabiting the underside surface of the bracts and wool survive the winter.

The latent period of $X$. ampelinus depends on many factors such as climate (Ridé and Marcelin 1983), and the bacterium can survive for several years on the grapevine without inducing symptoms. Therefore, the bacteria are likely to begin to proliferate when the humidity and temperature increase to levels that support growth (Grall and Manceau 2003). Here, we showed that bacterial DNA was detected even in leaves with no symptoms that were collected from a vineyard throughout the 2013 growing season (Table 3). In Hokkaido, the bacterium was first identified in 2009 (Shinmura et al. 2012); however, the plants may have been infected several years earlier, with the disease becoming more severe over time in vineyards that were latently infected. Because the average amount of rain was higher during the summer of 2009 and the temperatures were lower than normal, a burst of bacterial growth may have suddenly induced symptoms. Although recent incidence of the disease has been low, the bacteria may have spread more widely, thereby increasing the potential for future outbreaks. Our findings indicate that it is necessary to monitor bacterial distribution in various vineyards so that latent bacteria can be detected and preventive methods deployed to avoid an outbreak.

Acknowledgments We thank Mr. Y. Inagawa (HRO, Kamikawa Agricultural Experiment Station) for his support during the field surveys and Dr. M. Saito (HRO, Central Agricultural Experiment Station) for her helpful comments and encouragement. Thanks are also extended to the agricultural extension workers and the grapevine producers in Yoichi-town and Furano-city.

Open Access This article is distributed under the terms of the Creative Commons Attribution License which permits any use, distribution, and reproduction in any medium, provided the original author(s) and the source are credited.

\section{References}

Bradbury JF (1991) Xylophilus ampelinus. IMI descriptions of fungi and bacteria no. 1050. Mycopathologia 115:63-64
Grall S, Manceau C (2003) Colonization of Vitis vinifera by a green fluorescence protein-labeled, $g f p$-marked strain of Xylophilus ampelinus, the causal agent of bacterial necrosis of grapevine. Appl Environ Microbiol 69:1904-1912

Grall S, Roulland C, Guillaumès J, Manceau C (2005) Bleeding sap and old wood are the two main sources of contamination of merging organs of vine plants by Xylophilus ampelinus, the causal agent of bacterial necrosis. Appl Environ Microbiol $71: 8292-8300$

Kageyama K, Komatsu T, Suga H (2003) Refined PCR protocol for detection of plant pathogens in soil. J Gen Plant Pathol 69:153-160

Lopez MM, Gracia M, Sampayo M (1981) Studies on Xanthomonas ampelina Panagopoulos in Spain. In: Proceedings of the Fifth Congress of the Mediterranean Phytopathological Union, Patras, Greece. Hellenic Phytopathological Society, Athens, pp 56-57

Manceau C, Grall S, Brin C, Guillaumes J (2005) Bacterial extraction from grapevine and detection of Xylophilus ampelinus by a PCR and microwell plate detection system. Bull OEPP/EPPO Bull 35:55-60

Minsavage GV, Thompson CM, Hopkins DL, Leite RMVBC, Stall RE (1994) Development of a polymerase chain reaction protocol for detection of Xylella fastidiosa in plant tissue. Phytopathology $84: 456-461$

Nakaune R, Nakano M (2006) Efficient methods for sample processing and cDNA synthesis by RT-PCR for the detection of grapevine viruses and viroids. J Virol Methods 134:244-249

Panagopoulos CG (1969) The disease "tsilik marasi'" of grapevine: its description and identification of the casual agent (Xanthomonas ampelina sp. nov.). Ann Inst Phytopathol Benaki 9:59-81

Panagopoulos CG (1987) Recent research progress on Xanthomonas ampelina. Bull OEPP/EPPO Bull 17:225-230

Ridé M (2000) Bactérioses de la vigne. In: Ridé M, Boudon-Padieu E, Walter B (eds) Maladies à virus, bactéries et phytoplasmes de la, vigne edn. Féret, Bordeaux, France, pp 77-118

Ridé M, Marcelin H (1983) La nécrose bactérienne de la vigne (Xanthomonas ampelina). Bull Tech Pyrénées Orient 106:5-45

Ridé M, Ridé S, Novoa D (1977) Donnés nouvelles sur la biologie de Xanthomonas ampelina Panagopoulos, agent de la nécrose bactérenne de la vigne. Ann Phytopathol 9:87

Rowhani A, Chay C, Golino DA, Falk BW (1993) Development of a polymerase chain reaction technique for the detection of grapevine fanleaf virus in grapevine tissue. Phytopathology 83:749-753

Shinmura A, Horita H, Inagawa Y (2012) Occurrence of bacterial blight of grapevine caused by Xylophilus ampelinus in Japan (in Japanese). Jpn J Phytopathol 78:60

Willems A, Gillis M, Kersters K, Van Den Broecke L, De Ley J (1987) The taxonomic position of Xanthomonas ampelina. Bull OEPP/EPPO Bull 17:237-240 